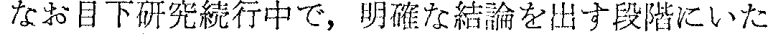
っていないが，現在生肉類变質度判定の一方法とされて いる $\mathrm{pH}$ 值执よび官能的判分と，この Pt-K 值との間に 興味ある関係が諗められる。

本研究に当り，御指導をいただいた当所食品部長川城
博士に媣く感謝する。また試料購入に際し，御便宜を与 えられた食肉加工協会に梁謝する。

\section{文献}

1）森茂樹：農化 20，315.(1944)；2) Beckman Bulletin 190-C ; 3) ibid. 99-D.

\title{
フェノールフタレイン・ジフォスフェイトナトリウム を用いる牛乳中フォスファターゼの定量法
}

\author{
德島大学薬学部 吉而寅吉 谷 労
}

1945 年 Huggins ${ }^{1)}$ らは水に対する溶解性の大きなフ オスファターゼ基質として,フェノールフタレイン・ジフ オスフェイトナトリウムを合成し，それによって血清持 よび尿などの中のフォスファターゼを缹量しているが， われわれはこの定量とは別の研究目的から，たまたま本 試薬の追試合成の機会を得たので，それを利用して本試 薬による牛乳中フォスファターゼの簡易定最を試みたと ころ, 非常化簡篻な操作で, 殺菌乳中 $1 \%$ 前後の生牛乳 の混入を鑑別できること拈よびさらに定量条件を追求す れば，本試薬によっても充分フォスファターゼの定量が 可能であるとの尒報的奏験成績を兄たので，報告する。

1. フェノールフタレイン・ジフォスフェイトナトリ ウムの合成

(1) 攪抖器および温度計をつけた $500 \mathrm{cc}$ の四ッロフ ラスコを用意し，あらかじめその中によく乾燥したオキ シ塩化燐 $50 \mathrm{~g}$ (30 cc) とク口ロホルム $50 \mathrm{cc}$ の混合物

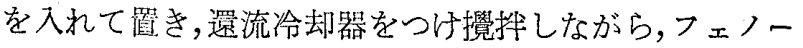
ルフタンイン $32 \mathrm{~g}$ (0.1 M) を加える。このときは伍と んど発熱をともなわない。固体と液体が一様に混和する と，フラスコを氷で泠しながら，さきにフェノールフタ レインを入れた口に滴下漏斗をつけ, 乾㰒ピリジン $25 \mathrm{cc}$ を洬下する。このとき，烈しい発熱をともなうから，反 応が常に $5^{\circ}$ 以下で進行するようにピリジンの㵜下速度 を調節する。冷却攪挥を約 5 時間続けたのち，反応を完 結させるために，一夜反応液を放㯰する。

(2) 反応液々室温 $40^{\circ}$ に保ち，アスピレータで減㞋 にして大部分のクロロホルムを除き，ふたたび冷却攪捧 しながら䄪水 $100 \mathrm{cc}$ を徐々に滴下して, 過剩のオキシ 塩化橉を分解すると，塩酸の生成とともに白い沈澱を形 成してくる.この反液に $40 \%$ 水酸化ナトリウム液を加 えてさきに生成した日沈をふたたび溶解する。このとき
反応液は微量の遊離フェノールフタレインのために，微 紅色を呈する。

(3)このアルカリ性反応液からピリジンを除くため に，2回エーテルで抽出を繰返したのち，水層をふたた び強塩酸で酸性にすると, 粘解性のフェノールフタレイ

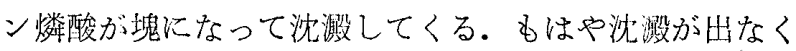
なるまで，塩酸を加え上曆液を捨てる．つぎに粘着性の 沈澱を集め，デシケータ（塩化カルシウム）中で $2 \sim 3$ 日乾燥したのち，乳鉢で粉䂗する。

(4)このよ5にして合成した粗製のフェノールフタレ イン燐酸をなるべく小量のメチルアルコールに溶解す る.この溶液に，あらかじめ然水アルコールに金属ナ トリウムを溶解して作って置いたナトリウムエチラート のアルコール溶液を，沈激が生成しなくなるまで添加す る. 生成したフェノールフタレイン・ジフォスフェイト ナトリウムを上周から洞別したのち, 手早くアルコー ル拈よびエーテルで洗浄して脱水する, 以上の操作によ って生成物はすでに遊離のフェノールフタレインを含ま ず，したがってその水溶液をアルカリ性にしても紅色を 呈しない。

(5) 生成物そメチルアルコール・ホルムアミド混液 (4：1）に溶解し，これに無水アルコールを添加して 再析出ざせ精製する。最後にアルコールおよびエーテル で沈澱至洗って乾燥し, 密閣容器に入れ, 冷暗所に保 存する.この状熊で保存すると無期間にわたり非常に安 悠である。

(6) 分析值：文献に見られる本品の分子式 $\mathrm{C}_{20} \mathrm{H}_{13}$

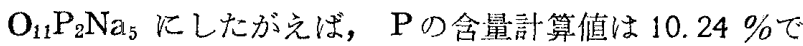
あるが,われわれの実験値では 9.27〜9.46\%であった. 収量率は正確に求めなかったが，粘着性沈測の処理を」 手に尔党ば，常に高収量が得られた。 
2. フェノールフタレイン・ジフォスフェイトナトリ

ウムによるフォスファターゼの定量

本法の原理は, 菻アルカリ性緩衝液中で, 本試薬に試 料中のフォスファターゼが作羽すると，この試楽からフ ェノールフタレインが遊離し，その量に応じて箯色し，

これを比色法で测定する。いか方ると，本試薬ば從来

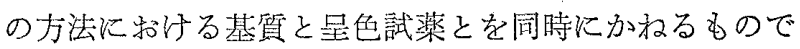
岁る。

試薬 緩衝液： 小少 $\left(\mathrm{Na}_{2} \mathrm{~B}_{4} \mathrm{O}_{7} \cdot 10 \mathrm{H}_{2} \mathrm{O}\right) 28.427 \mathrm{~g}$ 学水 $900 \mathrm{cc}$ に溶かし，これに水酸化ナトリウム $3.27 \mathrm{~g}$ を加光，さら水を加它て $1,000 \mathrm{cc}$ とする（昭和 30 年 改訂前に行われていたフォスフォターゼ試験のホウ酸塩 緩衙液をとのまま用いる。 $\mathrm{pH}$ 9.6〜9.7，25)。

基質液：フェノールフタレイン・ジフォスフェイト ナトリウム $2 \mathrm{~g}$ を水 $100 \mathrm{cc}$ に溶かす。
試験方法 試料牛孚 $1 \mathrm{cc}$ ，基質液 $1 \mathrm{cc}$ 㘧よび緩衝液 $1 \mathrm{cc}$ 順次 $10 \mathrm{cc}$ の目盛つき共栓試験管に入れ，水を 加えて $10 \mathrm{cc}$ にする。つぎに約 3 時間，37〜 40 の水浴 中にときどき振りながら浸し，刘照の完全殺菌乳の呈色 と比較して生乳混入の有無を判定する.

試験成績 殺菌乳に 1\%の牛乳を混入した検体では， 明らかにフェノールフタンインの星色を起し，たやすく 刘照と判別できる.24洔閫值では $0.6 \%$ 位の混入まで鑑 別可能になる。また比較の目的で薬学会協运法のフォス ファターゼ試験を同一試料について同時に行い，フェハ 一ル単位を測定してみると，第 1 表の最下欄に示す通り であり，協定法の方が感度の点で優れているが，是色の 時間的变化を較べると, 本法の力が Gibbs 試薬の是色 よりはるかに安定である。

第 1 表 混大生乳の鑑別試験成績

\begin{tabular}{|c|c|c|c|c|c|c|c|c|c|c|c|c|}
\hline & 間 & 乳(v/v\%) & 0 & 0.2 & 0.4 & 0.6 & 0.8 & 1.0 & 2.0 & 3.0 & 4.0 & 5.0 \\
\hline 3 & 時 & 間 做 & - & - & - & - & \pm & + & $\#$ & $H$ & 册 & HIlt \\
\hline 24 & & " & - & - & \pm & + & $H$ & $H$ & Hllt & HHt & thlls & Hillt \\
\hline 7 & $x>$ & ル単位 & 0 & 6 & 12 & 18 & 24 & 30 & 60 & 90 & 120 & 180 \\
\hline
\end{tabular}

\section{3. 牛乳中フォスファターゼの概測定量}

上述の実験方法にしたがい，呈色した試料の色㹂度 を，簡単な光電比色棓を用いて比色定量した（汇光板 $550 \mathrm{~m} \mu$, 液槽 $1 \mathrm{~cm})$.

な初50倍水稀釈生乳による呈色の吸収曲線を第 1 図に 示产.

第1図フェノールフタンイン・ジフォスフェイト ナトリウムの生非乳中のフォスファターゼに 上る是色（50倍水稀秋生牛乳，3時閪）

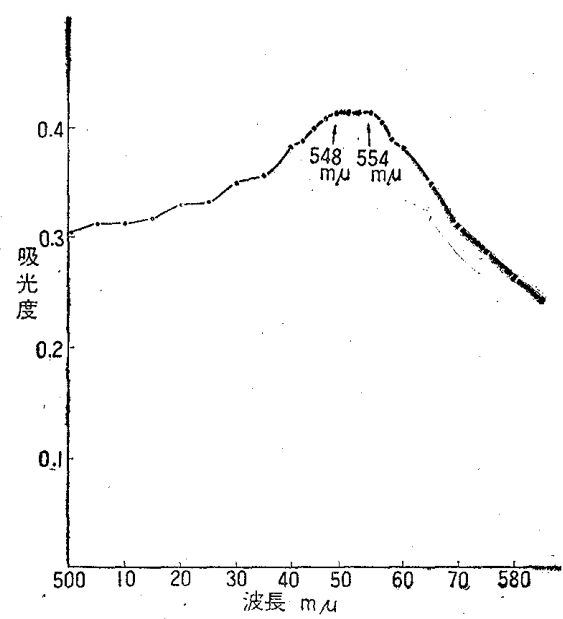

試験方法 殺菌乳と生乳を水でそれぜれ50倍および 20倍に稀积したものを原液として用意し，との扣の拉の

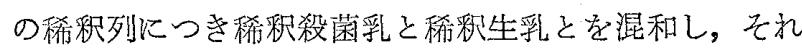
ぞれ生乳の $20 ， 40 ， 60 ， 80 ， 100 \%$ 混入した殺菌乳安作 りこれらの谷稀釈混合乳を試料とし，本法で呈色させ て吸光度堂測定した。

試験成績 第 2 図の通りである。

第2図 フェノールフタレイン・ジフォスフェイトナト リウムスよる生乳中のフォスファターゼの检翼線

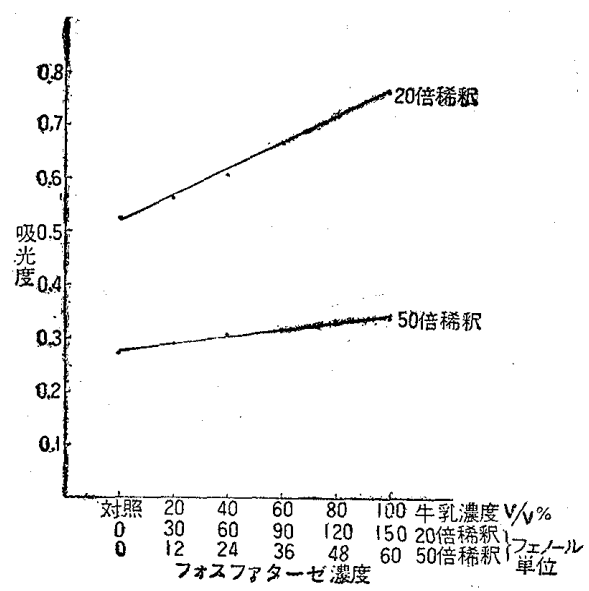


各稀种列ともフォスフォターゼ濃度 (生乳濃度) と吸 光度の関係は直線的であり，吸光度を泪定することによ って，フォスファターゼの定量が可能であることを示し ている. 50倍稀釈列では, 酵素濃度変化の割合に吸光度 の変化が少く，测定誤差が大きくなるので，20倍稀釈位 が適当なようである．またこれ以上稀釈倍数を小さくす ると, 牛乳自体の白溜にさまたげられ, 全般的に光の透 過率が減少して測定不能となる。

\section{むすび}

本報は予報的なもので，とくに発色条件についての梌 討が不十分であるが，一応本法による牛乳中のフォスフ マターゼの定量を薬学会協定の Gibbs 試薬法と此較す ると，その欠点は次の通りである。

(1)是色飞要する時間が長く，(2)試験条件の検討が十分 でないことが大きな原因と思われるが，試薬の感度が Gibbs 試薬法に抏よばない。
つぎにその長所はつぎの通りである。

(1) 同一の陚薬でもって同時に二つの働をきなし， たがって用いる試薬の数が少く, 定睹法全体の操作が非

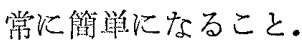
8

(2) 呈任そのものが非常に安定であること。

(3) 除琶白質の操作が省略されること.

な颃今後本試薬による発色条件の検討，フェノールフ タレイン法基準にした新たなフォスファターげ単位の決 定, ベックマン分光光電光度部によるフォスファター一ゼ の是量等について，さらに研究を進める予定である.

終りに当り，本研究に関する文苚を呈供された本学医 学部眼科学教室の高木助教授に深く謝意を表する。

文献

1) C. Huggins, P. Talalay : J. Biol. Chem. 159,

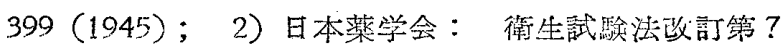
版（昭27）和よび改訂第13版（昭30).

\title{
植物体中のモノフルオロアセトアミドの残留試験
}

\author{
国立衛生試験所 川城 縓 竹内末久
}

浸透性殺虫剂モノフルオロアセトアミド $\left(\mathrm{FCH}_{2} \mathrm{CON}\right.$ $\mathrm{H}_{2}$ ）は，昆虫のみならず，温血動物飞対しても相当の毒 性をるっている1).よってこれを果樹に撒布した場合の 果実中の残留試験を行い，試験植物としては夏橙果実を 用いた。

有機性弗素を和機不掉登性㸝㨞に分解する方法には，

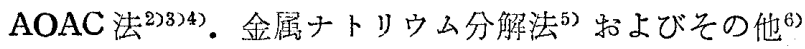
の方法があるが，堀内は AOAC 法と金属ナトリウム分 解法とを比較し，後者がすぐれていると報告している?。

弗索を妨害物質から分離する方法には，水蒸気蒸留 法89910) とイオン交換獄脂法1112113) とがあるが，本試 験の検体の费素含堊は，1 ppm なたはそれ以下であるの で, 蒸留法を用い, 装置は Mavrodineanu 等10) のもの を用いた。この方法では，検出率が98〜101\%であると いう。

定量法には，非常に多くの方法が発表されている。す なわらロダン鉄法 ${ }^{14)}$ ，鉄・アセチルアセトン法 ${ }^{15)}$ ，鉄・ フェロン法 ${ }^{16)}$, 鉄・サリチル酸法 ${ }^{17)}$, 鉄と種々の有機化 合物化上る方法 ${ }^{18)}$, ジルコニウム・アリザリン法 ${ }^{19220}$, 打よびその変法212 27)，ジルコニウム・キンアリザリン 法 $^{28)}$, ジルコニウム・プルプリン法29)，アルミニウム・ ヘマトキシリン法 ${ }^{1130) 311}$, アルミニウム・エリオクロー
ムシアニン法32)，トリウム・アリザリン法 ${ }^{19333)}$ 招よびそ の他 ${ }^{34) ~ 43)}$ がある.

以上の比佉のうら，妙害イオンの影響が比較的少 く,かつ繁用されているトリウム・アリザリン法とジル コニウム・アリザリン法とを比較した，前者はSalsbury の方法5)，後者汇 Bumsted の方法24を用いた、トリウ ム法は比色火要する時問は少いが，ジルコニウム・アリ ザリン法が約 5 倍鋭解であったので，定鼠はジルコニウ ム・アリザリン法を用いた。

\section{実験の部}

\section{1. 比色法の検討}

(1) トリウム・アリザリン法

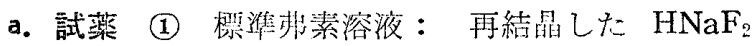
$0.0163 \mathrm{~g}$ を水に溶かして 1 Lとする.この溶液 $1 \mathrm{cc}$ はF

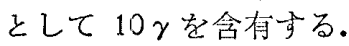

(2) アリザリンスルホン酸ナトリウム液：アリザリ ンスルホン酸ナトリウム $0.0744 \mathrm{~g}$ 沓に溶かしで $1 \mathrm{~L}$ とする.

(3) 硝酸トリウム液： $\operatorname{Th}\left(\mathrm{NO}_{3}\right)_{4} \cdot 4 \mathrm{H}_{2} \mathrm{O} \quad 0.24 \mathrm{~g}$ 打よ び $\mathrm{Na}_{2} \mathrm{SO}_{4} \cdot 10 \mathrm{H}_{2} \mathrm{O} 61.8 \mathrm{~g}$ を水に溶かし，これに酶酸 （比重 1.2）39 cc 拉よび水酸化ナトリウム $17.4 \mathrm{~g}$ を加 光，さらに水を加えて全量を500 cc とする。 